\title{
TINDAKAN MENGANCAM MUKA POSITIF KEPADA BARBIE KUMALASARI DALAM GELAR WICARA HOTMAN PARIS SHOW: KAJIAN PRAGMATIK
}

\author{
Syifa UI Qalbi \\ Pendidikan Bahasa dan Sastra Indonesia \\ UIN Syarif Hidayatullah Jakarta \\ Jalan Ir. H. Juanda No.95 Ciputat \\ surel: syifaul.qalbi17@mhs.uinjkt.ac.id
}

\begin{abstract}
Abstrak
Tujuan penelitian ini adalah untuk mengetahui tuturan-tuturan yang mengandung tindakan mengancam muka positif kepada Barbie Kumalasari yang diucapkan oleh Hotman Paris dan Melaney Ricardo dalam gelar wicara Hotman Paris Show pada episode "Musibah Membawa Berkah". Metode penelitian ini menggunakan deksripsi kualitatif dengan teknik simak dan catat. Hasil penelitian ini adalah terdapat dua belas pernyataan dari Hotman Paris dan Melaney Ricardo yang mengandung tindakan mengancam muka positif kepada Barbie Kumalasari, dari dua belas pernyataan tersebut terdapat kategori merendahkan, ungkapan yang tidak sopan, ketidaksetujuan atas pernyataan, dan menghinakan. Namun di antara empat kataegori tersebut, kategori merendahkan termasuk yang paling banyak dilakukan oleh Hotman Paris dan Melaney Ricardo kepada Barbie Kumalasari.
\end{abstract}

Kata Kunci: Tindakan Mengancam Muka Positif, Barbie Kumalasari, Hotman Paris, Melaney Ricardo

\begin{abstract}
The purpose of this study was to determine the utterances containing positive face-threatening actions to Barbie Kumalasari spoken by Hotman Paris and Melaney Ricardo in the Hotman Paris Show talk show in the episode "Disaster Brings Blessings". This research method uses qualitative descriptions with listening and note-taking techniques.The result of this research is that there are twelve statements from Hotman Paris and Melaney Ricardo which contain positive face threatening actions to Barbie Kumalasari. Of the twelve statements there are categories of demeaning, disrespectful expressions, disapproval of statements, and insulting. However, among the four categories, the degrading category is the one that Hotman Paris and Melaney Ricardo do the most to Barbie Kumalasari.
\end{abstract}

Keywords: Positive Face Threatening Action, Barbie Kumalasari, Hotman Paris, Melaney Ricardo

\section{A. PENDAHULUAN}

Manusia menggunakan bahasa dalam kegiatan sehari-hari untuk berkomunikasi. Bahasa digunakan sebagai alat untuk menyampaikan berbagai macam informasi baik itu secara lisan maupun tulisan. Bahasa juga merupakan tindakan budaya yang digunakan manusia untuk menciptakan dan menyampaikan melalui gagasan, ide, dan perasaannya (Kramsch, 1998). Hal ini sejalan dengan pendapat Chaer yang mengatakan bahwa tuturan dapat diekspresikan melalui dua bentuk yaitu lisan dan tulisan. Dalam bentuk lisan, pihak yang melakukan tindak tutur adalah penutur (pembicara) dan lawan tuturnya (pendengar), sedangkan dalam bentuk tulisan, tuturan tersebut disampaikan oleh penulis (penutur) kepada lawan tuturnya (pembaca) (H.G Tarigan, 2009). 
Dalam berkomunikasi ada beberapa unsur yang harus diperhatikan, salah satunya adalah unsur kesopanan atau kesantunan. Unsur kesopanan atau kesantunan dalam berinteraksi mengacu pada unsur-unsur bahasa (kalimat, kata atau ungkapan) yang digunakan (Abdul Chaer, 2010), hal ini dimaksudkan untuk menciptakan hubungan yang baik dan dapat memunculkan rasa hormat terhadap diri orang lain serta mempererat hubungan sosial mereka. Yule mendefinisikan kesantunan sebagai cara yang dilakukan untuk menunjukkan kesadaran seseorang terhadap citra diri lawan bicaranya (George Yule, 1996). Saling menghormati citra diri masing-masing merupakan hal yang bersifat umum dan ingin dimiliki oleh setiap orang. Namun pada kenyataannya, kita tidak dapat terus menerus menyampaikan tuturan yang santun atau menemui dan mendengar orang yang selalu menyampaikan tuturan santun kepada kita ataupun orang lain. Apalagi di era modern ini orang-orang dengan mudahnya menyampaikan segala macam tuturan tanpa memikirkan perasaan dan mengabaikan prinsip-prinsip kesantunan tersebut baik itu secara langsung maupun melalui sosial media. Hal tersebut tentunya dapat menyinggung perasaan orang lain atau mengancam muka lawan tutur.

Sebagaimana yang telah dijelaskan sebelumnya, bahwa tuturan yang digunakan saat berinteraksi haruslah menjaga perasaan lawan tutur. Menurut Brown dan Lavinson ada dua properti yang harus dilakukan saat berinteraksi, yaitu nosi muka atau citra diri dan face sebagai citra diri publik dimana setiap orang ingin dihargai atau diakui kapasitas rasional dalam mode konsiten penalaran dari tujuan hingga makna yang diterima dari tujuan tersebut (P Brown and Stephen Levinson, 1987). Nosi muka ini terbagi menjadi dua, yaitu konsep muka positif dan konsep muka negatif. Konsep muka positif merupakan keadaan dimana penutur ingin harapan atau keinginannya diakui dan diterima setidaknya oleh beberapa orang, sedangkan konsep muka negatif adalah keinginan setiap orang untuk bisa melakukan tindakannya dengan leluasa atau diberi keleluasaan oleh orang lain untuk melakukan suatu tindakan (P Brown and Stephen Levinson, 1987). Dalam kaitan pengaturan muka ini, tindak tutur dapat dibagi menjadi tindakan yang mengancam muka (Face Threatening Act/FTA) dan tindakan yang menyelamatkan muka (Face Saving Act/ FSA).

Hotman Paris Show merupakan sebuah talkshow atau gelar wicara yang dipandu oleh Hotman Paris dan Melaney Ricardo sebagai co-host dalam saluran televisi iNews setiap hari rabu dan kamis pukul 21.00 WIB. Hotman Paris yang juga berprofesi sebagai 
pengacara tersebut akan berbincang dengan narasumber dengan memberikan pertanyaanpertanyaan dengan ciri khasnya sebagai seorang pengacara. Dalam episode "Musibah Membawa Nikmat" dihadirkan seorang artis bernama Barbie Kumalasari. Dalam penelitian ini peneliti akan melihat bagaimana bentuk tindakan mengancam muka positif (positive face) yang dituturkan oleh Hotman Paris sebagai host dan Melaney Ricardo sebagai co-host kepada bintang tamu yakni Barbie Kumalasari. Barbie Kumalasari merupakan artis yang cukup dikenal oleh masyarakat belakangan ini dengan 'kehaluannya' yang mempunyai berbagai macam berlian yang disebut-sebut imitasi atau KW dan baru-baru ini juga sudah merilis sebuah lagu yang berjudul "Terima Kasih" .

Adapun dalam penelitian ini, penulis menggali informasi-informasi penelitian sebelumnya sebagai bahan pertimbangan untuk memperoleh landasan teori ilmiah, yakni: Melawati (2015) dengan judul "Tindakan Mengancam Muka Positif pada Film Seri New Girl Season 3: Kajian Pragmatik". Hasil penelitian ini menunjukkan bahwa (1) bentuk tindakan mengancam muka positif terdiri dari 11 bentuk, ketidaksetujuan 27,5\% data, 2) kritik 2,5\% data, 3) merendahkan 2,5\% data, 4) keluhan 5\% data, 5) penghinaan 7,5\% data, 6) pertentangan 7,5\% data, 7) tantangan 2,5\% data, 8) emosi yang tidak terkontrol $22,5 \%$ data, 9) ungkapan yang tidak sopan 10\% data, 10) ungkapan kabar buruk 5\% data, 11) ungkapan yang tidak kooperatif $7,5 \%$ data, dan (2) terdapat 4 jenis tindak tutur ilokusi yaitu 1) tindak tutur langsung literal 57,5\% data, 2) tindak tutur langsung tidak literal $25 \%$ data, 3) tindak tutur tidak langsung literal 10\% data, dan 4) tindak tutur tidak langsung tidak literal 7,5\% data.

Gayati dan Untung Yuwono (2013) dengan judul "Strategi Kesantunan dan Tindak Mengancam Muka Peserta dam Moderator dalam Tayang Bincang Indonesia Lawyers Club Episode "Denny: Advokat Koruptor=Koruptor". Simpulan dari penelitian ini adalah moderator menerapkan tindak mengancam muka dengan intensitas lebih tinggi daripada peserta acara yang lain yang disebabkan oleh factor kuasa antara penutur dan kawan tutur. Dalam acara ini, moderator memiliki kuasa yang lebih tinggi dalam mengendalikan acara.

Gunawan (2014) dengan judul "Representasi Kesantunan Brown dan Levinson dalam Wacana Akademik". Simpulan dari penelitian ini adalah strategi kesantunan negatif mahasiswa terhadap dosen meliputi penggunaan ungkapan tidak langsung, penggunaan ungkapan yang penuh kehati-hatian dan cenderung pesimis, penggunaan kata 
hormat, dan meminta maaf, sementara strategi kesantunan positif mahasiswa terhadap dosen berupa penggunaan penanda identitas kelompok, penggunaan basa-basi dan presuposisi, penggunaan penawaran dan janji, serta mencari alasan atau memberikan pertanyaan. Penelitian ini akan melihat bagaimana tuturan yang mengandung tindakan mengancam muka positif dan dikaitkan dengan konteks, jarak sosial, dan budaya.

\section{B. KAJIAN TEORI}

Ada empat strategi kesantunan (P Brown and Stephen Levinson, 1978) yang dapat dilakukan ketika berujar berdasarkan jarak sosial penutur dan penutur, status sosial penutur dan penutur, serta kedudukan relatif tindak tutur hal ini bertujuan untuk menjaga face lawan bicara dan menghindari FTA, yaitu:

a. Bald on record: Dilakukan secara langsung dengan mengabaikan konsep face. Alasannya karena strategi ini mengutamakan efisensi komunikasi dengan memenuhi empat maksim Grace yaitu maksim kualitas, kuantitas, relevansi, dan cara. Sehingga FTA dapat diminimalisir

b. Off record: Dilakukan secara tidak langsung yang mana penutur diizinkan untuk menafsirkan ujaran penutur secara mandiri . Tujuannya adalah untuk menghindari FTA secara langsung dengan melanggar maksim-maksim percakapan. Beberapa strategi off record:

a) Give hints : melanggar maksim relevansi dengan cara mengajak penutur untuk menginterpretasikan kaitan yang paling memungkinkan.

b) Be ambiguous: melanggar maksim cara dengan berkata ambigu.

c) Be vague: melanggar maksim cara dengan berkata samar.

c. Positive Politeness : Bertujuan untuk menjaga positive face lawan bicara dengan mengatakan hal-hal yang baik kepada kawan tutur. Beberapa sub-strategi dari strategi positive politencess:

a) Exaggerate (interest, approval, sympathy): penutur menunjukkan ketertarikannya kepada penutur dengan melakukan penekanan atau melebih-lebihkan ujarannya. Contohnya dengan menggunakan kata-kata penekanan, seperti 'for sure', 'really', 'exactly', 'absolutely', dan lainnya.

b) Avoid disagreement: penutur menghindari ketidaksetujuan antara dirinya dengan penutur dengan melakukan white lies atau hedging opinions. 
c) Joke: Menggunakan lelucon untuk menyampaikan maksud kepada kawan tutur. Sub-strategi ini hanya berlaku apabila penutur dan penutur memiliki latar belakang yang sama.

d. Negative Politeness: strategi kesantunan ini dilakukan untuk menghindari FTA dengan menjaga negative face kawan tutur. Sub-strategi dari negative politeness:

a) Be conventionally indirect : mengungkapkan permintaan kepada penutur secara langsung dengan menggunakan indirect speech yang ditandai dengan adanya penggunaan hedges.

b) Minimize the imposition: meminimalisir daya ancam dengan menggunakan hedges, seperti 'just', 'exactly', 'only', 'merely', 'a little', 'a bit', dan lain-lain.

c) Give deference : penutur menyatakan rasa hormatnya pada penutur dengan merendahkan dirinya di depan penutur atau dengan menghormati penutur. Sehingga, perbedaan kelas sosial antara penutur dan penutur dapat dilihat. Menurut Brown dan Lavinson (P Brown and Stephen Levinson, 1978), ada beberapa tindakan yang bisa mengancam muka positif dan muka negatif orang lain. Tindakan mengancam muka negatif termasuk permintaan, pesanan, pengingat, saran, saran dan peringatan. Sedangkan tindakan mengancam muka postif ekspresi ketidaksetujuan, kritik, kontradiksi, ketidaksepakatan dan juga membawa kabar buruk dari pendengar.

Dalam Melawati juga dijelaskan mengenai bentuk-bentuk tindakan mengancam muka positif (PFTA) yang terdiri dari bentuk ketidaksetujuan (disapproval), kritik (critism), tindakan merendahkan (contempt), keluhan (complaints), dakwaan (accusations), penghinaan (insult), pertentangan (contradictions), tantangan (challenges), emosi yang tidak terkontrol (out of control emotions), ungkapan yang tidak tidak sopan (irreverence), ungkapan kabar buruk (bringing of bad news), ungkapan mengenai topik yang memecah belah pendapat (divisive topics), ungkapan yang tidak kooperatif (non cooperation in an activity), ungkapan mengenai sebutan ataupun hal-hal yang menunjukkan status lawan tutur pada perjumpaan pertama (use of address terms and other status marked identification in initial encounters) (Ikeu Melawati, 2015). 


\section{METODE PENELITIAN}

Metode yang digunakan dalam penelitian ini adalah deskripsi kualitatif. Data yang menggunakan metode kualitatif diungkapkan dalam bentuk kalimat serta uraian-uraian, bahkan dapat berupa cerita pendek (Burhan Bungin, 2001). Adapun penelitian ini bersifat deskriptif, sebab merupakan penggambaran tindak mengancam muka postif yang terdapat di dalam video dan kemudian dianalisis ke bentuk narasi. Data dalam penelitian ini diperoleh dengan cara menyimak video yang terdapat di dalam akun youtube Hotman Paris Show kemudian ditranskrip berupa tulisan menggunakan teknik catat yakni menjaring data dengan mencatat hasil penyimakan pada kartu data (T.M.J Kesuma, 2007). Data yang telah berhasil ditranskripsi kemudian dianalisis dengan melihat apakah data-data tersebut mengandung tuturan tindak mengancam muka positif menurut Brown dan Lavinson. Dari analisis ini diharapkan dapat ditemukan apa saja tuturan-tuturan Hotman Paris dan Melaney Ricardo yang dapat mengancam muka Barbie Kumalasari dalam tayangan gelar wicara Hotman Paris Show di iNews TV.

\section{HASIL DAN PEMBAHASAN}

Penuturan pada tayangan gelar wicara Hotman Paris Show di iNews TV dalam episode "Musibah Membawa Berkah" terdapat beberapa tindakan mengancam muka positif. Bentuk-bentuk tindakan mengancam muka positif yang dilakukan oleh Hotman Paris dan Melaney Ricardo sebagai host dan co-host adalah merendahkan, ungkapan yang tidak sopan, ketidaksetujuan atas pernyataan, dan menghinakan.

Penulis mengumpulkan dua belas pernyataan yang mengandung tindakan mengancam muka positif. Data yang dikumpulkan berupa penggunaan kalimat yang mengandung jenis dan bentuk tindakan mengancam muka positif yang sesuai dengan penelitian. Adapun hasil dan pembahasan penelitian tersebut adalah:

\section{Tuturan Merendahkan dan Tidak Sopan}

Barbie: Aduh abang ganteng. Kenapa kupingnya?

Hotman: Lu kok pede banget sih?

Barbie: Ini lho aku bawain kado buat abangku yang paling ganteng. Selamat ulang tahun. 
Tuturan "Lu kok pede banget sih?" merupakan sebuah kalimat yang dituturkan oleh Hotman Paris kepada narasumbernya yakni Barbie Kumalasari ketika pertama sekali masuk ke dalam studio setelah dipersilakan masuk oleh Melaney. Barbie langsung masuk sembari bernyanyi dengan beberapa bait lirik lagu miliknya yang baru saja dirilis, kemudian meghampiri Hotman Paris yang saat itu sedang menutup telinganya dengan posisi berdiri. Barbie sebagai bintang tamu menghampiri Hotman dengan kalimat "Aduh abang ganteng. Kenapa kupingnya?" yang kemudian dijawab oleh Hotman dengan kalimat "Lu kok pede banget sih? dengan nada tinggi dan terkesan sinis.

Barbie yang berusia 37 tahun berprofesi sebagai artis tersebut memanggil Hotman yang berusia 60 tahun dengan sebutan "abang". Sebutan "abang” lazim digunakan oleh orang-orang yang mengenal Hotman karena selain berprofesi sebagai pengacara dan host, Hotman juga merupakan pria keturunan Batak sehingga sering disapa dengan sebutan "abang". Sedangkan Hotman memanggil Barbie dengan sebutan "Lu" yang biasanya digunakan oleh teman sebaya atau sepantaran. Dalam konteks kebiasaan masyarakat Indonesia tuturan yang diucapkan Hotman kepada Barbie yaitu "Lu kok pede banget sih?" ketika tamu baru saja datang dan selesai bernyanyi, kemudian menutup telinga merupakan tindakan yang tidak sopan dan tidak menghargai. Sehingga tuturan "Lu kok pede banget sih?" termasuk ke dalam tuturan yang mengandung tindakan mengancam muka positif kategori merendahkan dan tidak sopan yang dilakukan oleh Hotman kepada Barbie.

\section{Tuturan Tidak Sopan}

\begin{tabular}{|ll|}
\hline Barbie & $:$ Ini lho aku bawain kado buat abangku yang paling \\
& ganteng. Selamat ulang tahun... \\
Hotman & $:$ Gak mau... \\
Barbie & $:$ Kok gak mau?
\end{tabular}

Tuturan "Gak mau" dari Hotman Paris terjadi pada saat Barbie membawakan sebuah kado sebagai hadiah ulang tahun kepada Hotman di studio. Namun, Hotman tidak mau menerimanya. Dalam tuturan ini Barbie menggunakan kata sapaan "aku" untuk menunjukkan dirinya sendiri. Kata "aku" biasanya diucapkan atau digunakan kepada kawan tutur yang sudah dekat atau kenal lama dengan kita. Dalam kebiasaan masyarakat 
Indonesia biasanya kita akan menerima dengan senang hati pemberian hadiah atau kado dari seseorang.

Tuturan "Gak mau" merupakan kalimat yang dapat mengancam muka Barbie Kumalasari karena dapat membuat malu dan tuturan yang tidak sopan apabila digunakan dalam konteks ditonton oleh masyarakat luas.

\section{Tuturan Merendahkan dan Menghinakan}

\begin{tabular}{|ll|}
\hline Hotman & Karena kamu diundang ke sini sebatas entertainment. \\
& Kalau saya terima-terima kado kamu nanti seolah-olah \\
& kaya mengkhianati klien saya. Ya jadi kita hanya \\
& diskusi sebatas dunia akting, tidak mau membahas \\
& kasus. Makanya yang saya tanya pertama suara kamu \\
& tadi kayak jangkrik bangun? Kamu latihan nyanyi, kau \\
& merasa suara kamu bagus? \\
Barbie & $:$ Bagus banget..internasional bang.
\end{tabular}

Tuturan "Karena kamu diundang ke sini sebatas entertainmen . Kalau saya terimaterima kado kamu nanti seolah-olah kaya mengkhianati klien saya. Ya jadi kita hanya diskusi sebatas dunia akting, tidak mau membahasa kasus. Makanya yang saya tanya pertama suara kamu tadi kayak jangkrik bangun? Kamu latihan nyanyi, kau merasa suara kamu bagus?" merupakan tuturan yang diucapkan oleh Hotman ketika menjawab pertanyaan dari Barbie mengapa tidak mau menerima hadiah atau kado darinya. Hotman menjawab pertanyaan Barbie dengan tuturan yang cukup panjang yang kemudian dilanjutkan dengan tuturan “....Makanya yang saya tanya pertama suara kamu tadi kayak jangkrik bangun? Kamu latihan nyanyi, kau merasa suara kamu bagus?” ini menunjukkan Hotman benar-benar ingin bertanya mengenai suara atau lagu yang dibawakan Barbie ketika itu.

Hotman menggunakan kata sapa "kamu" untuk merujuk Barbie dan "saya" untuk merujuk dirinya sendiri. Kata "kamu" dan "saya" bisa menggambarkan sebuah hubungan yang relatif dekat antara host dan narasumber. Namun, ketika bertanya tentang bagaimana tanggapan Barbie mengenai suaranya, Hotman menggunakan kata sapa "kau" yang menunjukkan ciri khasnya sebagai orang Batak. Dalam konteks kebiasaan masyarakat Indonesia tidak seharusnya seseorang mengkritik secara langsung dan dituturkan oleh host kepada narasumber. Kemudian merendahkan dan menghinakan orang lain dengan 
perumpaan memakai nama hewan. Dalam tuturan tersebut Hotman sudah dapat dikatakan mengancam muka Barbie Kumalasari.

\section{Tuturan Merendahkan dan Ketidaksetujuan atas Pernyataan}

\begin{tabular}{|lll|}
\hline Barbie & $:$ Internasional. Itu lagunya aja langsung di cover-cover di \\
& seluruh dunia. \\
Hotman & $:$ Siapa yang cover? \\
Barbie & $:$ Ha..orang-orang banyak bang. Di Indonesia aja udah viral \\
& banget
\end{tabular}

Tuturan "Siapa yang cover?" dituturkan Hotman ketika Barbie menjelaskan bahwa lagunya yang baru dirilis tersebut sudah dicover atau dinyanyikan oleh orangorang seluruh dunia. Tuturan tersebut mengandung ejekan atau merendahkan dan ketidaksetujuan atas pernyataan ditambah dengan nada yang tinggi dan raut wajah yang sinis. Tuturan "Siapa yang cover?” yang dituturkan oleh Hotman Paris termasuk ke dalam tindakan yang dapat mengancam muka Barbie Kumalasari.

Tuturan Ketidaksetujuan atas Pernyataan, Menghina, dan Merendahkan

\begin{tabular}{|ll|}
\hline Hotman & Viral gara-gara dianggap lu gak tau diri kali? Soalnya \\
& setiap gua posting lagu kamu tu, hampir seratus persen \\
& semua marah-marah sakit kuping gitu. \\
Barbie & $:$ Tapi buktinya kalau suaranya gak bagus kenapa abang \\
& posting?
\end{tabular}

Tuturan "Viral gara-gara dianggap lu gak tau diri kali? Soalnya setiap gua posting lagu kamu tu, hampir seratus persen semua marah-marah sakit kuping gitu" merupakan tuturan yang dilakukan oleh Hotman ketika Barbie mengatakan lagunya tersebut sudah viral dimana-mana khususnya Indonesia.

Pada tuturan ini Hotman menggunakan kata "lu" dalam kalimat "Viral gara-gara dianggap lu gak tau diri kali?", menggunakan kata "gua” dalam kalimat "Soalnya setiap gua posting lagu kamu tu....", menggunakan kata "kamu” dalam kalimat "Soalnya setiap gua posting lagu kamu tu.......". Tuturan dengan kata "lu" dan "gua" tersebut menggambarkan bahwa Hotman terkesan geram dengan pernyataan Barbie yang menyebutkan lagunya viral dimana-mana. Terlihat bahwa Hotman tidak konsisten 
terhadap kata sapaan yang digunakannya. Dalam konteks tuturan kebiasaan masyarakat Indonesia tidak seharusnya menggunakan kata-kata yang dapat menyinggung kawan tutur.

Tuturan yang diucapkan oleh Hotman tersebut dapat mengancam muka Barbie Kumalasari karena mengandung ketidaksetujuaan atas pernyataan Barbie, menghina dan merendahkan.

\section{Tuturan Merendahkan}

\begin{tabular}{|c|c|c|}
\hline Hotman & ( & $\begin{array}{l}\text { Saya posting karena mungkin itulah di Indonesia ini ya, } \\
\text { semakin aneh semakin dapat rezeki kali. }\end{array}$ \\
\hline Barbie & : & $\begin{array}{l}\text { Justru itu bang justru yang aneh itu yang langka. Tepuk } \\
\text { tangan dulu dong...Kalau gak aneh gak mungkin diposting. }\end{array}$ \\
\hline
\end{tabular}

Tuturan "Saya posting karena mungkin itulah di Indonesia ini ya, semakin aneh semakin dapat rezeki kali" merupakan tuturan yang diucapkan Hotman ketika menanggapi pertanyaan Barbie Kumalasari mengapa lagunya diposting oleh Hotman Paris di akun instagramnya.

Dalam tuturan tersebut dapat mengancam muka Barbie Kumalasari karena mengandung nuansa makna ejekan yang merendahkan. Dengan secara tidak langsung mengatakan bahwa suara Barbie Kumalasari aneh atau bisa dikatakan jelek.

\begin{tabular}{|lll|}
\hline Melaney & $:$ Bang..bang gak usah diterima bang palingan isinya \\
& barang-barang KW bang \\
Barbie & $:$ Kalau ngomong suka bener \\
Hotman & $:$ Gua takut justru yang dalamnya palsu \\
Barbie & $:$ O..ya Allah \\
\hline
\end{tabular}

Dalam tuturan "Bang..bang gak usah diterima bang palingan isinya barang-barang KW bang" merupakan tuturan yang diucapkan oleh Melaney kepada Hotman Paris selaku mitra tutur 1 yang kemudian langsung dijawab oleh Barbie Kumalasari dengan tuturan "Kalau ngomong suka bener" sebagai mitra tutur 2. Tuturan Melaney tersebut pun juga dijawab oleh Hotman Paris dengan jawaban "Gua takut justru yang dalamnya palsu". Dalam konteks ini Melaney sebagai co-host mencoba untuk merayu Hotman Paris agar menerima kado yang dibawakan oleh Barbie, namun Hotman enggan untuk 
menerimanya. Karena tidak kunjung diterima akhirnya Melaney bertutur seperti itu. Setelah Melaney menjawabnya, Hotman pun menimpalinya kembali dengan kalimat "Gua takut justru yang dalamnya palsu" yang bermaksud bahwa ia takut mendapatkan kado yang palsu dari Barbie karena Barbie juga dikenal sebagai artis yang memiliki barang-barang $\mathrm{KW}$ atau palsu.

Kata "Gua" yang diucapkan oleh Hotman menunjukkan bahwa ia mempunyai kedekatan yang relatif dekat dengan Melaney. Dalam tuturan Melaney dan Hotman ini pun dapat mengancam muka Barbie Kumalasari karena bermakna ejekan yang merendahkan.

\section{Hotman $\quad$ : Pengacara gak pernah gua liat lu bersidang di pengadilan}

Barbie $\quad$ : Kan lain cerita, kan jadi anak buah bang...

Tuturan "Pengacara gak pernah gua liat lu bersidang di pengadilan" yang dituturkan oleh Hotman, terjadi ketika Barbie menjelaskan bahwa berlian yang dimilikinya hasil dari profesi Barbie yang juga sebagai pengacara. Dalam tuturan ini dapat mengancam muka barbie kumalasari karena tuturan ini mengandung tindakan merendahkan.

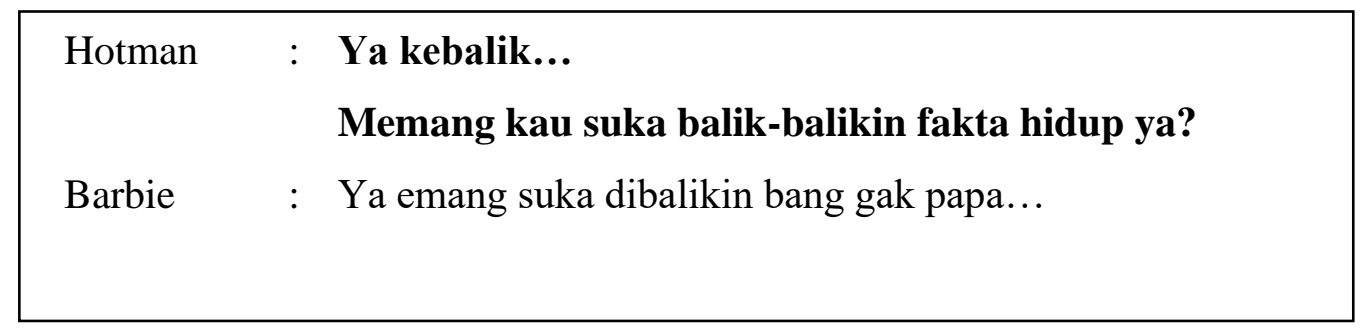

Tuturan "Ya kebalik...Memang kau suka balik-balikin fakta hidup ya?" merupakan tuturan Hotman ketika bertanya kepada Barbie mengenai istilah hukum yang kemudian dijawab salah karena terbalik oleh Barbie, yang seharusnya putusan awal Barbie menjawabnya dengan putusan akhir sehingga Hotman Paris menjelaskannya kepada Barbie.

Kata sapaan "kau" juga dipakai Hotman dalam tuturan ini. Dalam konteks kebiasaan masyarakat Indonesia kata sapaan "kau" mengandung kesan yang kasar, 
namun bagi orang yang bersuku batak kata "kau" merupakan hal yang lumrah. Dalam tuturan ini dapat mengancam muka Barbie karena mengandung sindiran secara tidak langsung yang ingin mengatakan bahwasanya Barbie bukan seorang pengacara dan tuturan tersebut dapat merendahkan Barbie Kumalasari.

\begin{tabular}{|lll|}
\hline Hotman & $:$ Bentar dulu.. \\
& Kalau ini ni.. asli gak? Orang ini bengkok begini..mana \\
& ada orang Indonesia bengkok begitu.. \\
Barbie & $:$ Kan aku blesteran.. \\
\hline
\end{tabular}

Tuturan "Bentar dulu..Kalau ini ni.. asli gak? Orang ini bengkok begini..mana ada orang Indonesia bengkok begitu..” tuturan Hotman tersebut dituturkan pada saat Hotman bertanya tentang barang-barang Barbie apakah semuanya asli atau palsu. Kemudian Hotman menunjuk bagian hidung Barbie Kumalasari dengan tuturan seperti itu. Dalam tuturan ini terdapat tindakan mengancam muka terhadap Barbie Kumalasari karena terdapat kata "bengkok" yang maksud tuturan tersebut mengandung ejekan yang merendahkan .

\begin{tabular}{|l}
\hline Melaney : Uuuh...Kamu pantesan gak Indonesia banget. \\
Blasteran Persia? \\
Blesteran Persia bang...berarti ponakan dong ama \\
kucing gua....
\end{tabular}

Tuturan "Uuuh... kamu pantesan gak Indonesia banget..Blasteran Persia? Blesteran Persia bang..berarti ponakan dong ama kucing gua...." merupakan tuturan yang diucapkan Melaney ketika Barbie Kumalasari mengakui bahwa ia keturuan Persia. Tuturan tersebut dapat mengancam muka Barbie karena menyamaratakan Barbie dengan kucing Persia, tuturan ini dapat merendahkan Barbie Kumalasari. 


\section{Melaney : Oke. Kalau gua boleh cut daripada kepanjangan, hari ini gua menyadari dari kecil emak gua selalu ngasih nasehat ama gua...biarlah dalam hidup ini yang waras ngalah..udah...duduk..duduk..silahkan duduk.. tepuk tangan..}

Tuturan "Oke..kalau gua boleh cut daripada kepanjangan..hari ini gua menyadari dari kecil emak gua selalu ngasih nasehat ama gua....biarlah dalam hidup ini yang waras ngalah..udah...duduk..duduk..silahkan" merupakan tuturan Melaney yang ditujukan kepada Barbie. Tuturan ini dituturkan Melaney dalam konteks Barbie Kumalasari mengakui kepada Hotman bahwa ibunya yang merupakan seorang Persia dan kakeknya seorang Belanda. Dalam tuturan ini dapat mengancam muka Barbie Kumalasari karena mengandung makna merendahkan dan menghinakan.

\section{E. SIMPULAN}

Pada penelitian ini dapat dilihat bahwasanya terdapat dua belas pernyataan dari Hotman Paris dan Melaney Ricardo yang mengandung tindakan mengancam muka positif terhadap Barbie Kumalasari dalam gelar wicara Hotman Paris Show episode "Musibah Membawa Nikmat”. Dari dua belas pernyataan tersebut terdapat kategori merendahkan, ungkapan yang tidak sopan, ketidaksetujuan atas pernyataan, dan menghinakan.Namun diantara empat kataegori tersebut, kategori merendahkan termasuk yang paling banyak dilakukan oleh Hotman Paris dan Melaney Ricardo. Penelitian ini juga menemukan bahwasanya terdapat ketidakkonsisten penggunaan kata sapaan yang dituturkan oleh Hotman Paris kepada narasumber seperti kadang-kadang menggunakan "kamu", "lu" dan "kau". Tindakan mengancam muka positif yang terdapat dalam penelitian ini secara konteks kebudayaan atau kebiasaan masyarakat Indonesia tidaklah lazim untuk dituturkan atau dikatakan.

\section{F. SARAN}

Penulis berharap penelitian ini dapat menjadi informasi tambahan mengenai penelitian tindakan mengancam muka positif (Face Threatening Act/FTA) serta dapat dijadikan bahan rujukan lebih lanjut bagi peneliti lainnya. Adapun bagi masyarakat, 
peneliti berharap dapat menumbuhkan kesadaran akan tuturan-tuturan yang diucapakan kepada kawan tutur sehingga tercapai keharmonisan saat melakukan interaksi baik kepada individu maupun masyarakat luas.

\section{DAFTAR PUSTAKA}

Abdul Chaer. (2010). Kesantunan Berbahasa. Rineka Cipta.

Burhan Bungin. (2001). Metodologi Penelitian Sosial (Format-format Kuantitatif dan Kualitatif). Airlangga University Press.

George Yule. (1996). Pragmatics. Oxford University Press.

H.G Tarigan. (2009). Pengajaran Pragmatik. Angkasa.

Ikeu Melawati. (2015). Tindakan Mengancam Muka Positif pada Film Seri New Girl Season: 3 Kajian Pragmatik (pp. 2-5). Universitas Widyatama.

Kramsch, C. (1998). Languange and Culture. Oxford University.

P Brown and Stephen Levinson. (1978). Universals of Languange Usages: Politeness Phenomena; in Esther Goody (ed.) Questions and Politeness Strategies in Social Interaction. Cambridge University Press.

P Brown and Stephen Levinson. (1987). Politeness: Some Universals in LanguangeUsage. Cambridge University Press.

T.M.J Kesuma. (2007). Pengantar (metode) penelitian bahasa. Carasvatibooks. 